\title{
Influence of Grazing on Age-Yield Interactions
}

\section{in Bitterbrush}

\section{BURT R. MCCONNELL AND JUSTIN G. SMITH}

Highlight: Significant relationships were found between yield and age of bitterbrush. Individual plants that were heavily grazed during the spring and early summer produced more forage than plants that were moderately grazed during late summer and fall. Under the heavy grazing treatment, however, plant longevity was sharply reduced and fewer plants survived until the age of maximum production. As a result, only $88 \mathrm{~kg} / \mathrm{ha}$ of air-dry forage was produced under heavy early-season grazing compared with $172 \mathrm{~kg} / \mathrm{ha}$ under moderate late-season grazing.

There is an apparent interaction between performance and age for most, if not all, perennial plants, but data are available for only a few species (Kershaw 1964). This interaction is important because it indicates the existence of a generalized pattern of building and degenerating growth phases in plant life cycles. If this relationship can be altered by grazing, it could have practical implications for managing key forage species for maximum long-term yields.

\section{Methods}

We undertook the present preliminary work to see if there is a meaningful relationship between yield and age in bitterbrush (Purshia tridentata) and, if so, whether it is influenced by grazing.

We made a fence-line comparison between two bitterbrush populations growing on a uniform site in the high desert country near Lakeview, Oregon. Both populations were intermingled with sagebrush (Artemisia tridentata). Bitterbrush plants on one side of the fence had been consistently heavily grazed (80-90\% removal of current twig production) by cattle-generally during the spring and early summer-and their crowns were low, compact, and tightly hedged. Plants growing on the other side of the fence received light to moderate use $(30-50 \%)$ by cattle during late summer and fall and had taller, more open-growing crowns. Both grazing treatments had been reasonably consistent for a minimum of 15-20 years prior to our study.

\footnotetext{
The authors are principal plant ecologist and former project leader (retired) with the Pacific Northwest Forest and Range Experiment Station, Forest Service, U.S. Department of Agriculture, La Grande, Oregon.

They wish to thank C. W. Ferguson of the Laboratory of Tree-Ring Research, University of Arizona, for making ring counts on many difficult specimens and rancher Con Flynn of Lakeview, Ore., for allowing the collecting of plants on his land.

Manuscript received April 10, 1976.
}

Other studies indicate that grazing during the spring and early summer is more detrimental to shrub vigor than grazing during late summer and fall; e.g., see McConnell and Garrison (1966) and Willard and McKell (1973). Therefore, season of use undoubtedly interacted with intensity of use and accentuated differences in grazing response on the two areas, but this did not interfere with our study objectives. Our main interest was in demonstrating the existence of a meaningful yield-age relationship in bitterbrush and determining whether it is influenced by grazing, so pronounced differences in grazing treatments were accepted.

A 2-acre (0.8-ha) study plot was fenced on each side of the division fence to protect plants from being grazed during the study period. Within each plot, representative samples of approximately 150 plants (excluding current seedlings) were selected to determine the age structure of each population. Because of the work involved, subsamples of 40 plants each were then randomly selected to establish comparative yield-age relationships for the two shrub populations. All current twigs over 0.5 inch were clipped from these plants, air dried, and weighed to the nearest $0.1 \mathrm{~g}$. Age was determined by counting growth rings with a low-power binocular microscope.

Polynomial regressions were fitted to these yield-age data from each grazing treatment, and regression surfaces were compared by covariance analysis. Age structures were compared by a chi-square test using a $2 \times$ c contingency table. Productivity rates for each shrub popu-

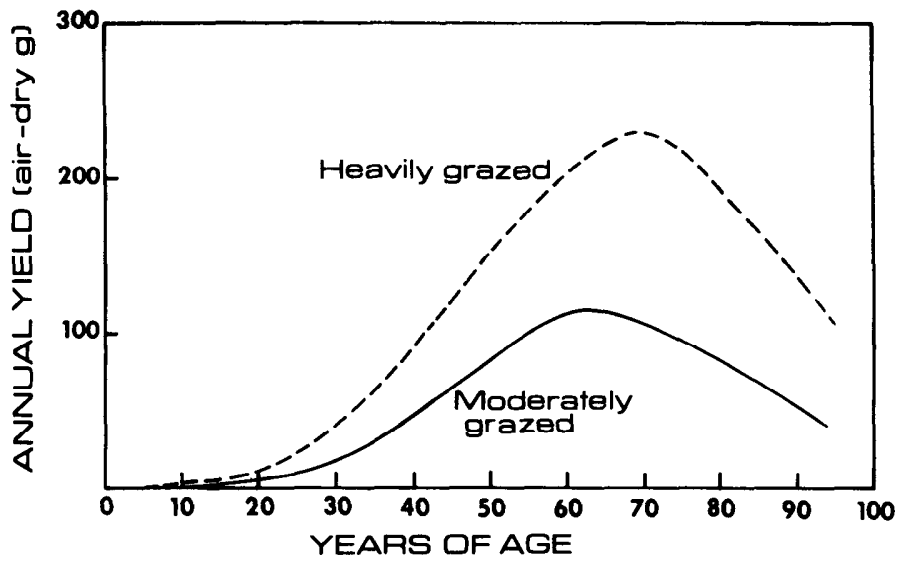

Fig. 1. Relationship between annual twig yield and age of individual bitterbrush plants under heavy early-season and moderate late-season grazing. 
lation were estimated from age-class densities and regressions of current twig yields on plant age. Similar correlations of production and size have been successfully used for other shrubs by Chew and Chew (1965), Kittredge (1945), Medin (1960), and Whittaker (1961).

\section{Results and Discussion}

Significant curvilinear regressions were found which indicated rising and falling trends between current twig yield (leaves and twigs) and the age of bitterbrush shrubs under both grazing intensities. The productivity of shrubs increased with age, reached a maximum at about 60 to 70 years, and then declined. Generally, yield-age trends were comparable in both shrub populations, although the strength of the relationship varied somewhat.

As variations in yield increased with age, we transformed these data logarithmically before conducting statistical tests. These tests indicated that $80 \%$ of the total variation in $\log$ yield
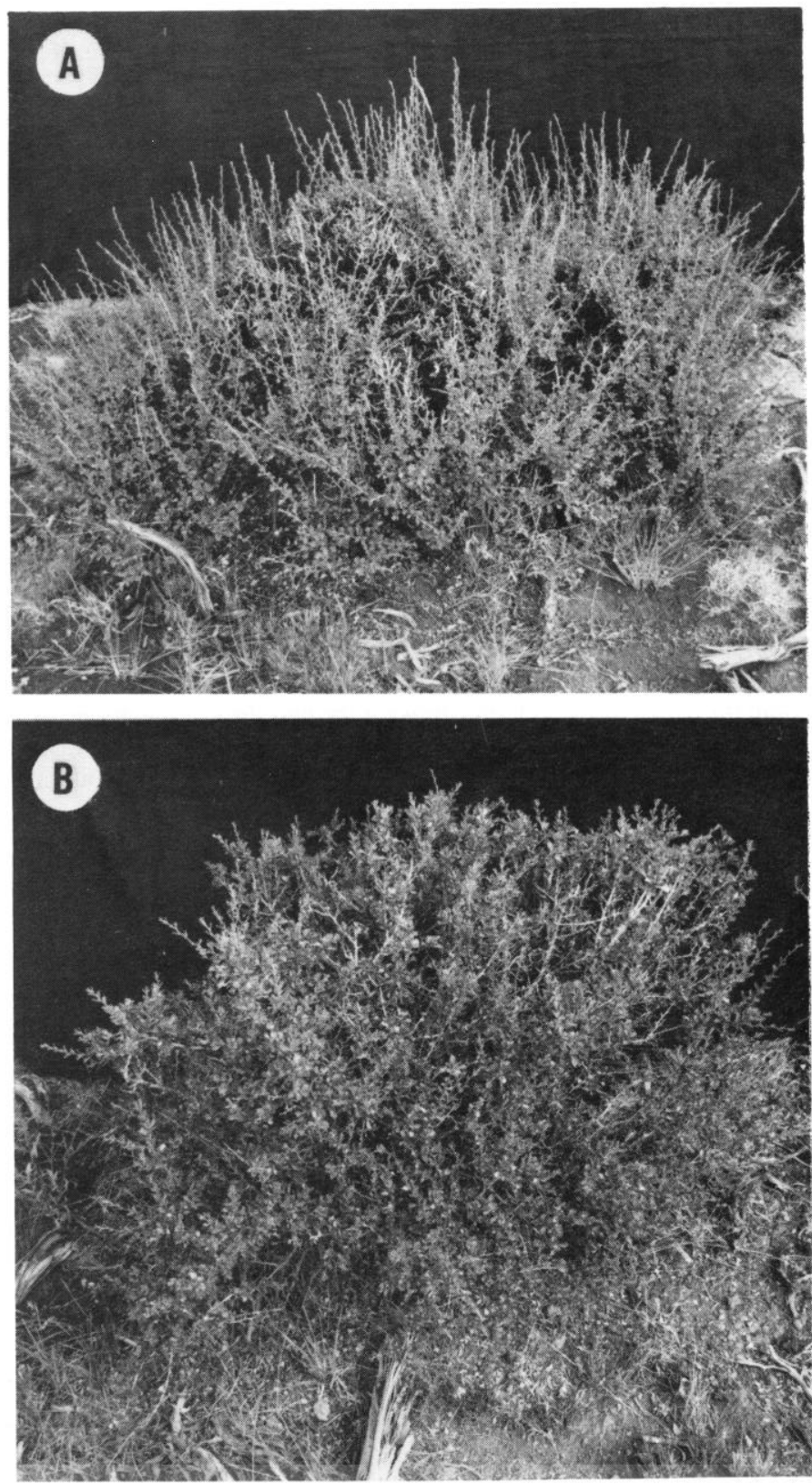

Fig. 2. Comparison of a heavily grazed $(A)$ and moderately grazed $(B)$ bitterbrush plant shows abundant growth of current twigs on heavily grazed plant was accounted for by age under heavy early-season grazing, in contrast with $69 \%$ under moderate late-season use. The estimating equations for these relationships in the two populations are

Heavily grazed:

$$
\begin{gathered}
\log \mathrm{Y}=-2.5398+0.2338(\mathrm{x})-0.0019\left(\mathrm{x}^{2}\right) \\
\mathrm{r}^{2}=0.80
\end{gathered}
$$

Moderately grazed:

$$
\begin{gathered}
\log Y=-0.1943+0.1640(x)-0.0012\left(x^{2}\right) \\
r^{2}=0.69
\end{gathered}
$$

where $\mathbf{Y}=$ logarithm of annual twig yield in air-dry grams/ plant, and $\mathbf{x}=$ plant age in years.

Covariance analysis used to compare these two regressions indicated that there was a significant difference between adjusted mean yields but no difference between net regression coefficients. Thus, when plotted, the transformed regressions would have identical slopes but different intercepts. However, to more clearly demonstrate the phasic relationships between yield and age, the transformed data in Figure 1 have been converted to arithmetic values. However, only a limited number of plants over 50 years of age were included in the heavily grazed sample. Since the yields of these older plants were also quite variable that portion of the curve in Figure 1 should be interpreted with caution. The same caution should probably also be used with Table 1.

Two interesting points are evident in the generalized yieldage relationships shown in Figure 1. First, heavy early-season grazing produced greater current twig yield per plant than moderate late-season grazing-even though continued for a prolonged period. This difference in production is well illustrated by Figure 2. Noticeably more leafage occurred on short spurs under moderate grazing (B) and considerably fewer current twigs were produced. In contrast, there was a pronounced increase in both length and number of current twigs on heavily grazed shrubs (A). This is possible because the heavily grazed shrubs had tightly sculptured crowns which protected enough leaf area within the plant crown to produce the reserve foods needed for abundant twig growth during periods of nonuse. Second, although increases and decreases in yield were greater for heavily grazed plants, peak yields were reached at approximately the same age (60-70 years) under both grazing treatments. Moreover, no noticeable increases in yield occurred until plants in each population were approximately 20 years old. Then, an apparent physiological threshold was reached and

Table 1. Comparative production profiles of bitterbrush populations by 10-year age intervals under heavy early-season and moderate late-season grazing.

\begin{tabular}{lcc}
\hline \hline & \multicolumn{2}{c}{ Average yield (air-dry kg/ha) } \\
\cline { 2 - 3 } $\begin{array}{c}\text { Age class } \\
\text { (years) }\end{array}$ & $\begin{array}{c}\text { Early heavy } \\
\text { grazing }\end{array}$ & $\begin{array}{c}\text { Late moderate } \\
\text { grazing }\end{array}$ \\
\hline $1-10$ & 2.08 & 0.16 \\
$11-20$ & 12.25 & 1.87 \\
$21-30$ & 11.92 & 7.29 \\
$31-40$ & 15.88 & 8.79 \\
$41-50$ & 17.09 & 34.79 \\
$51-60$ & 0 & 30.81 \\
$61-70$ & 0 & 23.78 \\
$71-80$ & 23.32 & 30.23 \\
$81-90$ & 5.42 & 29.13 \\
$91-100$ & 0 & 5.05 \\
Total & 87.96 & 171.90 \\
& &
\end{tabular}


yields increased sharply. After a short period of peak production, yields of plants in both populations declined with increasing age.

It is possible that the high rate of twig production under the heavy grazing treatment may also have been favored by certain other growth characteristics. For example, Bedell and Heady (1959) reported that twig elongation in chamise (Adenostoma fasciculatum) began earlier and lasted longer in hedgelike grazed plants than in ungrazed plants. It seems reasonable that such an increase in the overall length of the growing season might also occur in bitterbrush and that it would result in greater overall yields. As in bitterbrush, there also appeared to be an inverse relationship between degree of hedging and degree of flowering in chamise. The apparent stimulating effects of heavy twig removal have also been reported (Ellison 1960) for several other native shrubs; e.g., cliffrose (Cowania stansburiana), mountainmahogany (Cercocarpus spp.), and rabbitbrush (Chrysothamnus nauseosus). Ferguson (1973) put this growth response to practical use by topping stagnated bitterbrush plants to increase browse production on critical deer winter ranges. Berg and Plumb (1972) and Romberger (1963) provide a physiological background for understanding how twig growth is stimulated by clipping or grazing.

We point out, however, that the yield curves developed in Figure 1 present only half the story. The other half can be deduced from Figure 3, which shows comparative age compositions of the two study populations, and from Table 1, which shows their production profiles on a kilogram per hectare basis. Under heavy early-season grazing, the rate of mortality is apparently much higher (Fig. 3), and very few plants survived until the period of maximum yield at about 70 years of age. As a result, only about half as much air-dry forage per hectare is being produced under early heavy grazing (Table 1) as under late moderate use. It should be possible, however, to develop a system of grazing that will be capable of using this potential yield increment without appreciably affecting plant longevitya possibility that seems worth further study.

Densities of bitterbrush plants older than 1 year are also shown in Figure 3. There were 4,495 shrubs/ha under heavy early-season grazing compared with 5,058 shrubs/ha under moderate late-season use. A $t$-test indicated that these two densities were not significatly different at the 0.05 probability level. The ability of the heavily grazed population to maintain a level of density comparable with that of the moderately grazed population is due to a higher rate of seedling survival, which we believe is the result of a lower level of competition from associated understory species. An inventory of understory vegetation showed that cover of understory species, mostly cheatgrass (Bromus tectorum), on the moderately grazed area was nearly twice that on the heavily grazed area. Holmgren (1956) has shown that bitterbrush seedlings are generally unable to survive under such conditions. In addition, trampling may be

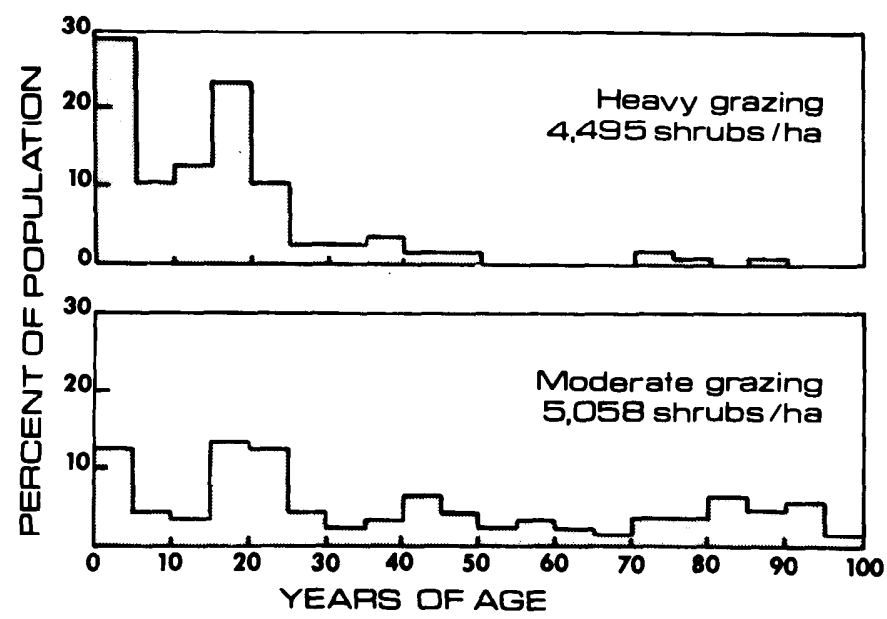

Fig. 3. Comparison of age structures of bitterbrush stands under heavy earlyseason and moderate late-season grazing. The age structures are significantly different at the 0.05 probability level. Plant density figures include all plants over I year of age.

operating as a natural planting phenomenon in the heavily grazed area to help maintain comparable population densities.

\section{Literature Cited}

Bedell, T. E., and H. F. Heady. 1959. Rate of twig elongation in chamise. J. Range Manage. 12:116-121.

Berg, A. R., and T. R. Plumb. 1972. Bud activation for regrowth, p. 279296. In: C. M. McKell, J. P. Blaisdell, and J. R. Goodin (Ed.), Wildland shrubs - their biology and utilization. U.S. Dep. Agr., Forest Serv., General Tech. Rep. INT-1. 494 p.

Chew, R. M., and A. E. Chew. 1965. The primary productivity of a desert shrub (Larrea tridentata) community. Ecol. Monogr. 35:353-375.

Ellison, L. 1960. The influence of grazing on plant succession of rangelands. Bot. Rev. 26:1-78.

Ferguson, R. B. 1973. Bitterbrush topping: Shrub response and cost factors. U.S. Dep. Agr., Forest Serv. Intermountain Forest and Range Exp. Sta. Res. Pap. INT-125. $11 \mathrm{p}$.

Holmgren, R. C. 1956. Competition between annuals and young bitterbrush (Purshia tridentata) in Idaho. Ecology 37:370-377.

Kershaw, K. A. 1964. Quantitative and dynamic ecology. American Elsevier Publ. Co., New York. 183 p.

Kittredge, J. 1945. Some quantitative relations of foliage in the chaparral. Ecology 26:70-73.

McConnell, B. R., and G. A. Garrison. 1966. Seasonal variations of available carbohydrates in bitterbrush. J. Wildl. Manage. 30:168-172.

Medin, D. E. 1960. Physical site factors influencing annual production of true mountain mahogany, Cercocarpus montanus. Ecology 41:454-460.

Romberger, J. A. 1963. Meristems, growth, and development in woody plants. U.S. Dep. Agr. Tech. Bull. 1293. 214 p.

Willard, E. E., and C. M. McKell. 1973. Simulated grazing management systems in relation to shrub growth responses. J. Range Manage. 26:171-174.

Whittaker, R. H. 1961. Estimation of net primary productivity of forest and shrub communities. Ecology 42:177-180. 